\title{
A Study of English Vocabulary Acquisition Strategies for Non-English Majors
}

\author{
Junrui Xu \\ Foreign Language School \\ Huanghe Science and Technology College \\ Zhengzhou, China
}

\begin{abstract}
Vocabulary learning occupies a very important position in college English teaching, and vocabulary acquisition has an important influence on students' language abilities and communication skills as well. Based on the strategies of English vocabulary acquisition put forward by Wen Qiufang and Hong Xianli, this research selects the sophomores of non-English majors in Huanghe Science and Technology College as the research objects, and focuses on the application of vocabulary acquisition strategies in foreign language teaching and the correlation between the use of vocabulary acquisition strategies and its effects on students' vocabulary learning. Meanwhile, some suggestions on college English vocabulary teaching and learning are put forward at last.
\end{abstract}

Keywords-non-English majors; vocabulary acquisition strategies; vocabulary teaching and learning

\section{INTRODUCTION}

Vocabulary is the carrier of information, a vital part of language, and it plays an important part in English learning. As British linguist Wilkins (1973) put it, "one can express a few things without grammar, but cannot express anything without words." However, due to various reasons, such as poor vocabulary, unthorough vocabulary understanding, language learners have difficulties in expressing themselves very well or accurately, communicating with others fluently, or obtaining the information from the texts. Therefore, to cultivate students' comprehensive abilities of listening, speaking, reading, writing and translation, the ability to accumulate vocabulary must be improved. According to the College English Syllabus promulgated by our country, college students should master at least 4500 English words for CET Band Four, 6200 for CET Band Six. But from the results of the CET exams, quite a number of students have not conformed to the requirements, which have affected the development of their various language skills to a certain extent. Therefore, for English language learners, their weakness in vocabulary is the "bottleneck" restricting their English learning (Fan Lin 2007:69-69)

Famous linguist Wen Qiufang said, “A series of studies on foreign language teaching showed that the differences in English learning strategies adopted by foreign language learners have a decisive impact on their performance when the other elements are the same." Vocabulary is an indispensable part of foreign language learning and it is an important basis for listening, speaking, reading, writing and translating skills as well. Vocabulary learning, which exists throughout the whole process of language learning, is the foundation of phonetics, grammar, discourse and all language skills. Therefore, for English learners, vocabulary is a key to language learning.

As for the traditional vocabulary teaching method, it gives priority to teachers' explanation, so teachers prepare lessons earnestly trying to enrich the content of the lecture after class. But most of the teaching activities focus on cramming method of teaching, that is, teachers try to explain language points straight and students accept them naturally without thinking. Such teaching method can not fully arouse the learning enthusiasm of students. What's more, in traditional teaching method, in order to explain words, teachers will often lead the students to read the words, and then write down the words on the blackboard, then list the meanings and usages of the words obtained from the dictionary and reference books, or use a certain number of examples to explain the words. At the same time, students are required to take notes carefully and memorize the notes as possible as they can. In the long run, such mechanical teaching methods will only make the students lose interest in vocabulary learning; therefore, it is more difficult to improve their vocabulary.

Thus, according to the requirement of English teaching reform, it is of great importance to master necessary strategies on vocabulary learning, and it is also essential to improve the quality of English teaching. In addition, it is beneficial for the students to master some strategies on vocabulary learning, which can be helpful to their language learning in their lifetime. Psychology holds the opinion that language learning is a continuous process throughout the entire life, and vocabulary learning is also the same. Mastering effective and proper vocabulary acquisition strategies can provide guarantee for language learners' further education after graduation. (Fan Lin 2007). As a result, it is vital to study and improve students' vocabulary acquisition strategies, especially the non-English major undergraduates, who account for the vast majority of foreign language learners in China. Based on the result of the survey on vocabulary learning among the non-English major undergraduates in Huanghe Science and Technology College, this paper has analyzed the use of vocabulary acquisition strategies among college students, and the correlation between the use of vocabulary acquisition strategies and its effects on students' vocabulary learning. Meanwhile, some suggestions 
on college English vocabulary teaching and learning are put forward at last.

\section{LITERATURE REVIEW}

\section{A. Language Learning Strategies}

1) Definition of language learning strategies: Since 1970s, many language scholars at home and abroad have defined learning strategies in different ways.

From Stem's point of view, strategy is best reserved or general characteristics of the approach adopted by the language learner." According to Bialystock (1978), learning strategy is a means of choosing useful information to improve language competence for language learners in the language learning. (p71). For Weinstein and Mayer(307-315), language learners take advantage of thoughts and behaviors to help their language learning in the process of learning, and these thoughts and behaviors are called learning strategies. O'Malley \& Chamot (1990) regard learning strategies as the special thoughts or behaviors that are used to help language learners to understand, learn, or reserve new information. And for Oxford and M Nyikos, language learning strategies are the methods that are used by language learners to improve their language abilities and make the learning more successful. (291-299). Cohen defines learning strategies as "behaviors used by learners with the purpose of improving their knowledge and understanding" (68).

2) Classification of learning strategies: Generally speaking, there are four kinds of classification on learning strategies.

O’Malley \& Chamot classify learning strategies into three aspects, that is, metacognitive strategies, cognitive strategies and social/affective strategies. According to O'Malley \& Chamot, metacognitive strategies are higher order executive skills, and they may entail planning, monitoring, or evaluating a learning activity. Cognitive strategies concentrate on the incoming information, controlling it in ways that can improve learning. Social/affective strategies involve either interaction with another person or ideational control of effect.

Cohen classifies language learning strategies into learning strategies and applying strategies according to the standard of applying strategies, and his study aims at the application of learning strategies.

Oxford divide learning strategies into two categories, that is, direct strategies and indirect strategies. According to her, direct strategies are about dealing with new language while indirect strategies are about the general management. Direct strategies have three subcategories: memory strategies, cognitive strategies compensatory strategies. Indirect strategies are also have three parts, metacognitive strategies, affective strategies and social strategies. Metacognitive strategies can help language learners control their own cognition, that is, coordinate their own learning process by using functions such as centering, arranging, planning and evaluating.

Chinese researcher Wen Qiufang classifies learning strategies into two categories: administrative strategies and language learning strategies. In her study, on the one hand, she stresses the relationship between learning strategies and learning process. On the other hand, she studied the relationship between learning strategies and learning materials. According to her, administrative strategies are relevant to learning process, while language learning strategies are related to language learning materials.

\section{B. Vocabulary Acquisition Strategies}

1) Definition of vocabulary acquisition strategies: Based on the various definitions of learning strategies above, this thesis attempts to define vocabulary acquisition strategies as general methods, specific behaviors, skills, or thoughts that language learners consciously take advantage of to enhance the ability of vocabulary learning and make vocabulary learning easier, faster and better.

2) Current status of researches on vocabulary acquisition strategies: In the 1960s, people began to pay more attention to language learning strategies. Since the late 1970s, a large number of studies on strategies on vocabulary memorizing for English speakers has emerged. At the same time, the researchers began to pay attention to how to memorize English vocabulary and other second language vocabulary. For the research on foreign language vocabulary strategies, it has experienced a long process. It was neglected at the very beginning, and then is taken seriously. The focus of the research was the teachers" "teaching", but now it stresses the "learning" of the students. Especially in the 1980s and 1990s, the research on foreign language vocabulary acquisition strategies gained fruitful achievements. During that time, many researchers did a great deal of studies on vocabulary acquisition strategies, such as Cohen Aphek (1981)/Porte (1988), O 'Malley (1990), Vann Cohen (1990). Michael J. Lanson and Donald Hogben (1996) did a research on fifteen Australian students who were learning Italian by Thinking Aloud Method. Schmitt (1997) made a large-scale survey on vocabulary acquisition strategies of Japanese learners. The results showed that rehearsal strategy accounted for the largest percentage among all vocabulary acquisition strategies.

However, most of the researchers took western learners as research objects, and they didn't involve Chinese students who were learning English as the second foreign language and how to learn English vocabulary for Chinese students was not told. (Melton 1990). Wen Qiufang (1996), one of the famous researchers on learning strategies, argued that English learning strategies included two subsystems --- concept and method. According to her argument, concept referred to the learners' understanding of "how to learn English well", and method was the actions taken by the learner to learn English well. Method was divided into management method and learning method.

In addition, researchers in China have done a lot of empirical studies on the concept of English vocabulary learning and strategies among Chinese learners. For example, based on the classification of learning strategies made by $\mathrm{O}$ 'Malley and Chamot, Wu Xia, Wang Qiang (1998) did a research on vocabulary acquisition strategies and their influence on vocabulary learning among the sophomores of non-English major, using the methods of questionnaire and 
vocabulary test. The result showed the students could not apply to other learning strategies well and they couldn't help performing rote tasks of memorization although they knew it was not the right way to study well. Wang Wenyu (1998), carried on an investigation on English vocabulary acquisition strategies among Chinese college students by means of quantitative analysis and vocabulary test. Zhou Dajun and Wen Boyan (2000), Deng Zhaochun (2001), and other scholars carried on detailed investigations about student's vocabulary, and they did some researches on the increasing of vocabulary and the correlation between students' vocabulary and language ability, using the method of questionnaire and vocabulary tests. Lv Wenpeng (2000) used "the depth and elaboration of processing theory "to do an empirical research on how to memorize difficult words. Fan Lin and Wang Qinghua (2002) used the Semantic Field Theory to prove that classification strategy can promote the students' memory of English words. In the communicative language teaching, Dong Yanping (2001) adopted both indirect and direct vocabulary acquisition strategies to help English learners, especially poor English learners, to improve their vocabulary output ability, and the results showed that direct vocabulary learning strategy is an effective supplement to indirect vocabulary learning strategy. Gai Shuhua (2003) explained how to implement vocabulary acquisition in reading by using Information Processing Theory.

According to the classification made by Wen Qiufang(1996), vocabulary learning strategies include cognitive strategy, memory strategy, reviewing strategy, recalling strategy and words application strategy. Based on this kind of classification, this research studies the vocabulary learning of students in Huanghe Science and Technology College.

\section{RESEARCH METHOD AND PROCESS}

\section{A. Research Method}

In this study, two kinds of methods are adopted, questionnaire and test. The questionnaire consists of fourteen items, which are designed according to the five vocabulary acquisition strategies classified by Chinese famous scholar Wen Qiufang, that is, cognitive strategy, memory strategy, reviewing strategy, recalling strategy and words application strategy. Each item is graded by the students according to their actual performance. The scores are divided into five grades, namely, $5=$ always use, $4=$ often use, $3=$ occasionally use, 2 $=$ donnot use, 1 = never use. In addition, in order to understand students' mastery of vocabulary better, the author asks the subjects o take a test on vocabulary. The words are all from the textbook they are learning-New Horizon College English Book 3 (Edition 2). The content of the test includes the meaning of the words, part of speech, word formation, antonyms and synonyms.

\section{B. Research Process}

1) Subjects: The subjects that participate in this study are all sophomores from non-English majors in Huanghe Science and Technology College. They are from four different classes, namely, Class 1 (28 students) and Class 2 (30 students) of
Accounting major, Class 1 (32 students) and Class 2 (30 students) of Computing major. They use the same teaching material-New Horizon College English Book 3 (Edition 2).

2) Data collection: The author distributes 120 questionnaires and vocabulary test papers respectively to the students and asks them to hand them in without names after finishing them. At last, there are 110 effective copies. The questionnaire consists of fourteen items, which are designed according to the five vocabulary acquisition strategies classified by Chinese famous scholar Wen Qiufang, that is, cognitive strategy, memory strategy, reviewing strategy, recalling strategy and words application strategy. Each item is graded by the students according to their actual performance. The scores are divided into five grades, namely, $5=$ always use, $4=$ often use, $3=$ occasionally use, $2=$ don not use, $1=$ never use. In addition, in order to understand students' mastery of vocabulary better, the author asks the subjects o take a test on vocabulary. The words are all from the textbook they are learning New Horizon College English Book 3 (Edition 2). The content of the test includes the meaning of the words, part of speech, word formation, antonyms and synonyms.

3) Data analysis: The author analyzes the 110 valid questionnaires and vocabulary test, and the results are shown in "Table I" and "Table II" respectively.

TABLE I. ANALYSIS ON THE USE OF VOCABULARY ACQUISITION STRATEGIES

\begin{tabular}{|c|c|c|c|}
\hline \multicolumn{2}{|c|}{ Items } & \multirow{2}{*}{$\begin{array}{l}\text { Average } \\
3.59\end{array}$} & \multirow{2}{*}{$\begin{array}{r}\begin{array}{r}\text { Standard } \\
\text { Deviation }\end{array} \\
1.53\end{array}$} \\
\hline cognitive & dictionary & & \\
\hline strategy & words guessing & 2.54 & 1.32 \\
\hline \multirow{4}{*}{$\begin{array}{l}\text { memory } \\
\text { strategy }\end{array}$} & key words & 3.17 & 1.76 \\
\hline & words list & 3.31 & 1.30 \\
\hline & $\begin{array}{l}\text { learn words from the } \\
\text { contexts }\end{array}$ & 3.09 & 1.28 \\
\hline & $\begin{array}{l}\text { using of images or } \\
\text { imagination }\end{array}$ & 2.71 & 1.27 \\
\hline \multirow[t]{2}{*}{$\begin{array}{l}\text { reviewing } \\
\text { strategy }\end{array}$} & $\begin{array}{ll}\text { reviewing } & \text { for } \\
\text { consolidation } & \end{array}$ & 2.32 & 1.22 \\
\hline & $\begin{array}{l}\text { regular review for } \\
\text { avoiding forgetting }\end{array}$ & 2.21 & 1.03 \\
\hline \multirow[t]{3}{*}{$\begin{array}{l}\text { recalling } \\
\text { strategy }\end{array}$} & $\begin{array}{l}\text { observing the } \\
\text { meaningful part of } \\
\text { the words }\end{array}$ & 3.31 & 1.11 \\
\hline & $\begin{array}{l}\text { recalling special } \\
\text { symbol of the word }\end{array}$ & 3.22 & 1.05 \\
\hline & $\begin{array}{l}\text { spelling new words in } \\
\text { mind }\end{array}$ & 3.12 & 1.43 \\
\hline \multirow[t]{3}{*}{$\begin{array}{l}\text { words } \\
\text { application } \\
\text { strategy }\end{array}$} & $\begin{array}{l}\text { Applying new words } \\
\text { in a variety of } \\
\text { contexts }\end{array}$ & 2.23 & 1.32 \\
\hline & $\begin{array}{l}\text { Exercising } \quad \text { new } \\
\text { words in different } \\
\text { ways }\end{array}$ & 2.42 & 1.21 \\
\hline & $\begin{array}{l}\text { Trying to learn and } \\
\text { apply the words }\end{array}$ & 3.35 & 1.31 \\
\hline
\end{tabular}
one which is less than 3 is considered to be don not use or never use.

As shown in "Table I", respondents showed little significant difference in terms of the use of vocabulary strategies. In order to further study the influence of vocabulary 
acquisition strategies have had on vocabulary learning, the author analyzed the results of the vocabulary test. The result is shown in "Table II" as follows:

TABLE II. RESULTS ON VOCABULARY TEST

\begin{tabular}{|l|l|l|l|l|l|}
\hline \multicolumn{4}{|l|}{ Scores } \\
\hline Items on & $17-20$ & $13-16$ & $9-12$ & $5-8$ & $0-4$ \\
\hline $\begin{array}{l}\text { Tests } \\
\text { words } \\
\text { meaning }\end{array}$ & $15.65 \%$ & $11.71 \%$ & $9.74 \%$ & $10.68 \%$ & $51.89 \%$ \\
\hline $\begin{array}{l}\text { Tests on part } \\
\text { of speech }\end{array}$ & $16.59 \%$ & $24.43 \%$ & $33.28 \%$ & $20.46 \%$ & $4.83 \%$ \\
\hline $\begin{array}{l}\text { Tests on } \\
\text { word } \\
\text { formation }\end{array}$ & $4.87 \%$ & $18.54 \%$ & $25.41 \%$ & $29.31 \%$ & $21.48 \%$ \\
\hline $\begin{array}{l}\text { Tests on } \\
\text { antonyms } \\
\text { and } \\
\text { synonyms }\end{array}$ & $34.27 \%$ & $23.5 \%$ & $13.61 \%$ & $17.56 \%$ & $10.64 \%$ \\
\hline
\end{tabular}

As shown in "Table II", more than $60 \%$ of students attach great importance to the meaning of the words; more than $50 \%$ of the students attach importance to word formation, but part of speech and antonyms and synonyms are not valued. However, the understanding and mastering of the part of speech decided the understanding and using of the words to a great extent. The fact that students don't pay attention to these two aspects reflects their weakness in vocabulary learning. Moreover, when students study vocabulary, most of them memorize don't conform to English speech habits.

TABLE III. THE CONTRAST BETWEEN VOCABULARY ACQUISITION STRATEGIES AND THE RESULTS OF THE VOCABULARY TEST

\begin{tabular}{|l|c|c|c|c|c|}
\hline $\begin{array}{l}\text { Vocabulary } \\
\text { Acquisition } \\
\text { Strategies }\end{array}$ & \multicolumn{5}{|l|}{ The Results of the Vocabulary Test } \\
\cline { 2 - 6 } & $\mathbf{9 1 - 1 0 0}$ & $\mathbf{8 1 - 9 0}$ & $\mathbf{7 1 - 8 0}$ & $\mathbf{6 1 - 7 0}$ & $\mathbf{0 - 6 0}$ \\
\hline $\begin{array}{l}\text { cognitive } \\
\text { strategy }\end{array}$ & $34.22 \%$ & $4.86 \%$ & $9.75 \%$ & $10.75 \%$ & $40.14 \%$ \\
\hline $\begin{array}{l}\text { memory } \\
\text { strategy }\end{array}$ & $10.74 \%$ & $18.59 \%$ & $12.71 \%$ & $31.32 \%$ & $26.42 \%$ \\
\hline $\begin{array}{l}\text { reviewing } \\
\text { strategy }\end{array}$ & $15.66 \%$ & $17.61 \%$ & $23.48 \%$ & $25.41 \%$ & $17.65 \%$ \\
\hline $\begin{array}{l}\text { recalling } \\
\text { strategy }\end{array}$ & $20.51 \%$ & $23.47 \%$ & $27.41 \%$ & $16.63 \%$ & $11.72 \%$ \\
\hline $\begin{array}{l}\text { Words } \\
\text { application } \\
\text { strategy }\end{array}$ & $18.63 \%$ & $35.23 \%$ & $26.42 \%$ & $15.62 \%$ & $3.87 \%$ \\
\hline
\end{tabular}

From "Table III", we can see that the results of the vocabulary test are proportional to the use of vocabulary acquisition strategies. In addition, the results show that the students who get higher scores prefer to use cognitive strategy, while the students who get lower scores hardly use words application strategy.

\section{IMPLiCATION IN LANGUAGE TEACHING}

Based on the analysis on the correlation between the use of vocabulary acquisition strategies and the grades students get, the author puts forward some suggestions on college English vocabulary teaching.

- The teaching objectives should be clear, and the teaching form should be diversified. It is better to divide students into several groups, and try to motivate each student to participate in the group activities, for example, discussing questions with each other, share ideas with each other, or cooperate with each other. In group activities, students can easily perceive the vocabulary that closely related to their learning purpose, which will help them to reinforce or enhance their understanding towards the words.

- In language teaching, teachers should pay more attention to cultivating students to use vocabulary acquisition strategies to memorize and enlarge vocabulary, and try to increase the width and depth of lexical knowledge gradually according to the rules of the development of vocabulary. Besides, teachers should use vocabulary acquisition strategies consciously in the process of vocabulary teaching. Great importance should be attached to the strategy of guessing the meaning of the words from the context, and increasing the recurrence rate of the new words in the context as much as possible, which will help students to understand the words better and use what they have learned more accurately. Moreover, encourage students to memorize words by repetition and review the words regularly to remember the words as long as they can.

- Metacognitive strategy training should be emphasized. Metacognitive strategy has an indirect effect on the second language acquisition. By cultivating students to use metacognitive strategies can help students to select the best cognitive strategies for their study and improve the efficiency of vocabulary learning. more effectively.

- Teachers should pay attention to the application of the vocabulary in specific language contexts in vocabulary teaching. Try to help students develop a good habit of vocabulary learning, improve learning efficiency, enhance their confidence in English learning. Only in this way can students promote comprehensive capability of English learning.

\section{CONCLUSION}

To sum up, vocabulary acquisition strategies play an important role in language learning. Therefore, teachers must pay enough attention to the application of vocabulary acquisition strategies in teaching, guide students to use the strategies consciously in the process of learning, and help students develop a good learning habit. Only when the vocabulary acquisition strategies are employed properly, can the students' vocabulary be improved and other language skills are cultivated in the process of language learning.

\section{REFERENCES}

[1] Bartlett, E C. Remembering: A study in Experimental and Social Psychology [M]Cambridge: Cambridge University Press, 1932.

[2] Benson, P. Teaching and Researching Autonomy in Language Learning. London: Longman.

[3] Cohen, A.D. Strategies in Learning and Using a second Language [M]. Beijing: Foreign Language Teaching and Research Press, 2000:108-113. 
[4] Chamot A.D. The Learning Strategies of ESL Students. [M]. Learning Strategies in Language Learning. Englewood Cliff NJ: Prentice-Hall, 1987: 71-88

[5] Bialystok, E. "A Theoretical Model of Second Language Learning". Language Learning 28(1978):69-83

[6] Chamot, A. U. et al. 1999. The Learning Strategies Handbook [M]. NY: Longman.

[7] Harmer, J. The Practice of English Language Teaching. Harlow: Longman, 1991.34 O’Malley, J.M. \&A. U. Chamot. Learning Strategies in Second Language Acquisition Cambridge: Cambridge University Press, 1990

[8] Hosenfeld, C. "Students' Mini-theories of Second Language Learning". Association Bulletin 29(1977):2.

[9] Oxford, R\&M Nyikos. "Variables Affecting Choice of Language Learning Strategies by University Students,". The Modern Language Journal, 1989(3):291-299.

[10] Rubin J. Study of Cognitive Process in Second Language Learning. [J]. Applied Li nguistics, 1981, 9 (3): 117-31

[11] Schmitt N, Mccarthy M. Vocabulary Desciption, Acquisition and Pedagogy [M]. Shanghai: Shanghai Foreign Language Education Press, 2002:183-92

[12] Politzer R L, Mcgroarty M. An Exploratory Study of Learning Behaviors and Their Relationship to Gains in Linguistic and Communicative Competence [J]. TESOL Quarterly, 1985, 19.

[13] Johnson, K. \& H. Johnson Encyclopedic Dictionary of Applied Linguistics: A Handbook for Language Teaching. New York: Blackwell Publishers Ltd., 1998.

[14] Oxford, R. Language Learning Strategies: What Every Teacher Should Know. New York Newbury House Publishers, 1990: 284-297.

[15] Fan Lin, Wang Qinghua, An Experimental Research on Classification Strategy in English Vocabulary Learning. Foreign Language Teaching and Research, 2002(3).

[16] Wen Qiufang, English Learning Strategies. Shanghai: Shanghai Foreign Language Education Press, 1996

[17] Wen Qiufang, Trends and Characteristics of English Learning Strategies among College Students. Foreign Language and Foreign Language Teaching, 1996(4). 